\title{
Life cycle and morphological identification of Globodera spp. related to potato (Solanum tuberosum L.) phenology in Nariño, Colombia
}

\author{
Ciclo de vida e identificación morfológica de Globodera spp. relacionados \\ con la fenología de la papa (Solanum tuberosum L.) en Nariño, Colombia
}

Carlos Betancourth ${ }^{1}$; Juan-David Moran-Toro ${ }^{2}$; Luz-Mery Portillo-Rosero ${ }^{3}$; Lina-María Realpe-Realpe ${ }^{4}$; Katherine Urrego-Otero ${ }^{5}$

\begin{tabular}{|c|c|}
\hline & ARTICLE DATA \\
\hline 1 & $\begin{array}{l}\text { Professor, Ph.D. Universidad de Nariño, Facultad } \\
\text { de Ciencias Agrícolas. Pasto, Colombia, cbet70@ } \\
\text { yahoo.com }\end{array}$ \\
\hline 2 & $\begin{array}{l}\text { Undergraduate student, Agronomic Engineering } \\
\text { Universidad de Nariño, Colombia, juanmoran9t@ } \\
\text { gmail.com }\end{array}$ \\
\hline 3 & $\begin{array}{l}\text { Undergraduate student, Agronomic Engineering, } \\
\text { Universidad de Nariño, Colombia, luzme9311@ } \\
\text { gmail.com }\end{array}$ \\
\hline 4 & $\begin{array}{l}\text { Undergraduate student, Agronomic Engineering, } \\
\text { Universidad de Nariño, Colombia, linamaria-55@ } \\
\text { hotmail.com }\end{array}$ \\
\hline & $\begin{array}{l}\text { Undergraduate student, Agronomic Engineering, } \\
\text { Universidad de Nariño, Colombia, urregok2412@ } \\
\text { gmail.com }\end{array}$ \\
\hline
\end{tabular}

Cite: Betancourth, C.; Moran-Toro, J.D.; PortilloRosero, L.M.; Realpe-Realpe, L.M.; Urrego-Otero, K. (2021). Life cycle and morphological identification of Globodera spp. related to potato (Solanum tuberosum L.) phenology in Nariño, Colombia. Revista de Ciencias Agrícolas. 38(1). 97-110.

doi: https://doi.org/10.22267/rcia.213801.147

Received: January 212021.

Accepted: April 152021.

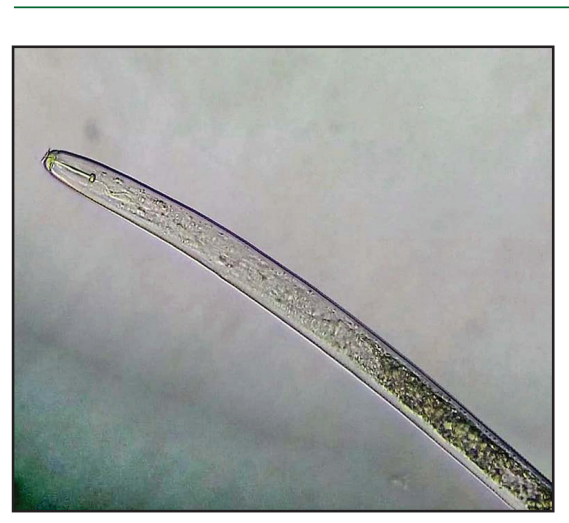

\section{ABSTRACT}

Nematodes of Globodera genus are considered one of the most important and limiting pests for potato crops, since these pathogens are difficult to control and cause losses between 20 and $50 \%$ of potato production. The study was carried out in Túquerres and Contadero, department of Nariño, Colombia. In these areas, cysts were collected by taking soil samples, obtaining immature females after observing the roots of potato plants and taking photographic records of symptoms in the crop. This study was carried out to determine the presence of nemathodes by studying their morphological characters such as: stylet's nodules shape e, stretch marks between the vulva and anus, the female color change towards the cyst formation, and the relationship between pathogen and host. Cysts viability tests were carried out, obtaining active larvae in J2 state. The findings confirm Globodera pallida species and no evidence of Globodera rostochiensis. There were chlorosis, yellowish spots on the foliage, and dwarf plants. The appearance of immature females coincides with the phenological stage of flowering, which occurs 90 days after the seeds sprouted.

Key words: cyst; Globodera; golden nematode; morphological characters; pallida; potato; samplings.

\section{RESUMEN}

Los nematodos del género Globodera son considerados una de las plagas más importantes y limitantes para el cultivo de papa, ya que estos patógenos presentan un difícil control y ocasionan pérdidas entre el 20 y $50 \%$ de la producción. El trabajo se realizó en las zonas de Túquerres y Contadero, pertenecientes al departamento de Nariño, Colombia, en donde se recolectaron quistes mediante la toma de muestras de suelo y la obtención de hembras inmaduras tras la observación de raíces de plantas de papa, también se tomaron registros fotográficos de los síntomas correspondientes a la presencia del nematodo durante el desarrollo fenológico del cultivo. El objetivo principal fue determinar mediante el 
estudio de caracteres morfológicos como: forma de los nódulos del estilete, estrías entre la vulva y ano y cambio de color en la hembra hacia la formación del quiste, la especie presente en las zonas mencionadas y relacionar el ciclo biológico del patógeno con el de su hospedero. Se realizaron pruebas de viabilidad de los quistes, obteniendo así larvas activas en estado J2. Los resultados evaluados correspondieron a la especie Globodera pallida y no se encontró evidencia de la presencia de Globodera rostochiensis en las muestras. En cuanto a los síntomas observados en campo, se presentó clorosis, manchas amarillentas en el follaje y plantas de escaso crecimiento. La aparición de hembras inmaduras coincide con la etapa fenológica de floración, la cual ocurre a los 90 días después de la emergencia de la planta.

Palabras clave: caracteres morfológicos; fenología; Globodera pallida; muestreos; nematodo dorado; papa; quiste.

\section{INTRODUCTION}

Potato is one of the main crops in Colombia, and growing it is the activity that generates the most direct rural employment. Studies by Valbuena et al. (2009) determined that potato phenological cycle has five stages: The first stage refers to the tuber shoot development and its emergence on the soil surface. In the second stage, the plant vegetative growth occurs with the elongation of main and secondary stems and leaves; roots and stolons growth occurs simultaneously; at this stage, the photosynthesis process begins.

The third stage involves the initial growth of the stolon hook and the appearance of the flower bud. The fourth stage corresponds to tuber cell expansion with accumulation of water, nutrients, and carbohydrates: Tubers demand the dry matter from the aerial part of the plant, and the maximum growth point of the foliar area of the plant is reached; flowering reaches its fullness. The fifth and last stage corresponds to the crop maturation, where leaves begin to senescence, turning yellow due to decreased photosynthesis rates and the gradual accumulation of dry matter in tubers. The tuber develops slowly until reaching physiological maturity. Later, the tuber epidermis fixation is reached.

Potato, like other crops, has a range of pathogens such as bacteria (Erwinia $s p$ ), viruses (PVY, PVX and PYVV), nematodes, and pest insects (Premnotrypes vorax and Tecia solanivora). This issue affects both the plant and its production, causing negative social and economic impact (MARD - Ministerio de Agricultura y Desarrollo Rural, 2019; SIPSA- Sistema de Información de Precios y abastecimiento del Sector Agropecuario, 2013). Among these pathogens, nematodes stand out and are considered the most limiting pest, especially the cyst formers. Within this group, Globodera rostochiensis (Wollenweber) Beherens (Nematoda: Heteroderidae) and Globodera pallida (Stone) Behrens are the most important because their main consequence is cyst formation in plant roots (Carreño, 2017; Rivas, 2005; Tarazón et al., 2006).

These pathogens have a rounded, elongated or filiform shape; they are microscopic in size and live mainly in soil and water (Jalata, 1986). They present differences between species in terms of their morphological characters such as the stylet nodules' shape and stretch marks between the vulva and anus. In addition, they present a marked sexual dimorphism that implies differences in the external physiognomy such as color, shape, and size between females and males (Brodie, 1996; Greco and Crozzoli, 1995).

Desgarennes et al. (2006) and Perry (1986) states that this nematode species shows a close synchrony with the biological cycle of 
its host. The reason is that the stimulus to reach the juvenile state J2 inside the egg is driven by radical potato exudates. When hatching and due to their natural openings, vulva and neck, potato exudates look for the root to infect it and feed themselves (Beltrán, 2016; Carrión and Rojas, 2013). It should be noted that the $\mathrm{J} 2$ stage has a survival period of around 3-7 days outside the host (Bates et al., 2002).

Once in the root elongation zone, they penetrate through the growth structures, heading towards the xylem, where they feed and remain for two or more additional molts (Franco, 1986). The female is permanently puncturing the adjacent cells of the syncytium with the stylet (Franco, 1986), until her development is complete in about 10 days, reaching her adult form. It is estimated that one biological cycle is generated per growing season (Fullaondo, 1999).

Given that the root is generally the most affected part, the main symptoms are plant dwarfism, foliar development stunting, and thin and sparse stems. Additionally, it is possible to observe cysts adhered to the absorbent roots of the plant and also some yellowing (Franco and González, 2011). It is considered the most unwilling pest, since they are the most damaging, recalcitrant, and cosmopolitan potato pest (Greco, 1993; Piedra et al., 2008). Globodera can cause a yield reduction between $20 \%$ and $50 \%$ when their population reaches between 16 and 32 eggs / g soil (Greco and Moreno, 1992) or when there is no manifestation of aerial symptoms, the estimated losses are 15\% (Carrión and Rojas, 2013; Franco, 1986). With an average density of 50 nematodes per 100 cubic centimeters in soil and 5 nematodes per 5 grams in roots, the nematode can cause yield losses of up to 50\% (Vera and Oliva, 2013).

Regarding the nematode distribution, $G$. rostochiensis species was detected in Germany in 1881 (Greco and Crozzoli, 1995). Then it spread to other European countries and other continents (Massae, 1913). In the United States, G. rostochiensis was detected in Long Island, New York in 1983 (Organization European et Mediterranean Plant Protection [OEPP], 2017; Organismo Internacional Regional de Sanidad Agropecuaria [OIRSA], 2015). In South America, both species have been found in Bolivia and Venezuela, but only G. rostochiensis predominates; conversely, in Ecuador and Peru only G. pallida has been found (Nieto, 1976).

Nieto et al. (1971) cite a survey administered by the Colombian Agricultural Institute (ICA). This indicated that the highlands of Nariño were highly infested (Baeza, 1972). In 1975, Colombia and The Netherlands signed an agreement focused on recognition and distribution of the potato cyst nematode, pathotypes determination, evaluation, and selection of resistant and tolerant varieties. Despite these investigations, in Colombia, no potato resistant varieties have been observed (Guerrero, 2012). For instance, potato varieties such as andigenic (Solanum phureja and $S$. andigenum) and those bred by the ICA (Crossings with $S$. tuberosum) are susceptible to this nematode (Dees et al., 1980).

This study was carried out to identify the nematode species of the genus Globodera in Túquerres and Contadero, department of Nariño, Colombia. The research focused on observing morphological character of juveniles and the color change in females. 
The dynamics between the crop and the pathogen were taken into account, including symptom expression during the development of the research work. Based on the evidence, Globodera was considered as a pest of economic importance.

\section{MATERIALS AND METHODS}

Location. Sampling was carried out in two locations: "Igua" village, municipality of Túquerres, Nariño, Colombia, at $01^{\circ} 04^{\prime} 10^{\prime \prime}$ North latitude and $77^{\circ} 35^{\prime} 37^{\prime \prime}$ West longitude, at $2988 \mathrm{~m}$ a.s.l. and "Loma de Yaez" village, municipality of Contadero, at $0^{\circ} 55^{\prime} 34^{\prime \prime} \mathrm{NL}$ and $77^{\circ} 32^{\prime} 28^{\prime \prime} \mathrm{WL}$, at $2950 \mathrm{~m}$ a.s.l. with temperature ranging between 12 and $18^{\circ} \mathrm{C}$.

Experimental area. The experimental lots with cyst nematode background were $918 \mathrm{~m}^{2}$. Two seeds per site of potato Diacol Capiro variety, susceptible to the nematode, were sown. The experimental units were homogenously managed.

Sampling. 27 200-gram sub-samples were collected in a zig-zag pattern. It has been proved that the bigger the number of subsamples, the greater the accuracy of the results (Centro International de Mejora de Maíz y Trigo - CIMMYT, 2007 and Instituto Internacional de Agricultura - IITA, 2007).

The samples were mixed and homogenized to obtain a composite sample of the whole plot. $100 \mathrm{~g}$ of composite sample were used for the subsequent procedure.

To get nematode females, 90 days after sprouting (flowering stage), the roots of 27 randomly selected plants were examined.

\section{Variables evaluated}

Description of symptoms. During the crop season, a general monitoring of the symptomatology was carried out.

Cyst Extraction from soil. The sieving method (sieve No. 30) and the Baermann funnel were used. This method consists in suspending the soil sample $(100 \mathrm{~g})$, in a 1000cc volumetric balloon (Zumeta, 2016). The suspension is transferred to the funnel, previously covered with filter paper, where cysts are attached. Dry samples were observed with a stereoscopic microscope (Figure 1).

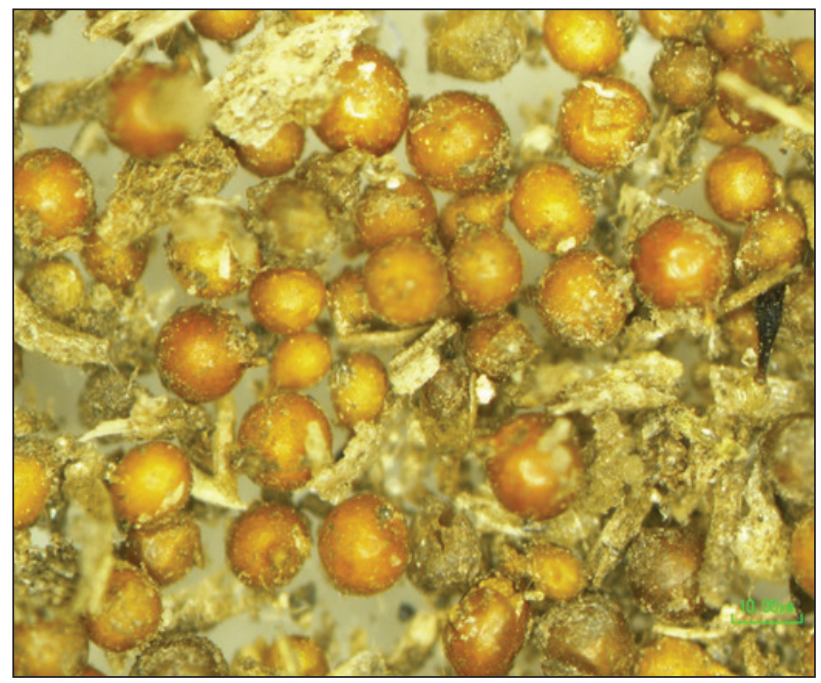

Figure 1. Globodera spp, nematode cysts. Source: self-made.

Female extraction. Immature female samples were taken from the root area and individually removed with help of forceps.

Petri dish viability test. This test was carried out in order to verify the level of cyst viability by using 27 Petri dishes. Each dish contained 10 cysts suspended in water obtained by drainage after potato crop irrigation. According to Valverde (2011), the root exudate produces the necessary stimulus 
for the hatching of the J2 larva. The cysts were under observation until they hatched. In a complementary way, cysts were randomly sampled and placed between two glass plates in order to press them and break them to observe the eggs and larvae inside them.

Finding juveniles. Juveniles emerged from the simulated natural hatching in the laboratory were used for their identification. The process consisted in transferring the larva to a slide in a drop of distilled water, relaxing the specimen through the use of heat. When it no longer showed movement, it was observed in the microscope at $40 \mathrm{x}$. For this procedure, 10 juveniles were used.

\section{Identification of the genus Globodera} spp. by morphological characters. The taxonomic keys used for the species identification were at the genus and species level based on morphological characteristics.

Characteristics were analyzed at cyst level. Nematode J2 larvae and immature females were preserved in glyceri for subsequent procedures in the laboratory. The plates with the juveniles were observed at 40x.

The characters observed were a change in the female's color, the shape of the basal nodule of the stylet, and the shape of the stretch marks between the anus and the edge of the fenestra. The preparation of perineal cuts of the females was carried out by cutting the head of the female. Then all the contained eggs were removed, washing the tissue and making parallel cuts on the edges of the body. The aim was to be able to stretch the tissue and observe the stretch marks between the anus and the vulva (Greco, 1993; Sañudo et al., 2003). For this test, 20 females were cut to verify the information.

\section{Relationship of the potato crop phenology} with the biological cycle of the nematode. Based on the literature reviewed and the observation of the potato phenological cycle in both areas, the purpose was to relate, in a general way, the nematode life cycle with the development of the crop. The aim was to determine which phenological stage is more susceptible to the nematode attack.

\section{RESULTS AND DISCUSSION}

Symptoms. During the crop cycle, similar symptoms were observed in both locations despite the difference in temperature between them. The most common symptoms were chlorosis, premature wilting, and yellowish spots on the foliage (Figure 2). In general, there were plants with reduced growth, distributed in patches and wilting on warm days (Figure 3). These findings agree with symptoms described by Tovar (2006), who claims that these symptoms can be confused with nutritional deficiencies in addition to having delayed flowering. Similar symptoms were described by Franco (1986), Godoy et al. (2013) and NPDRS - National Plant Disease Recovery System (2013). 


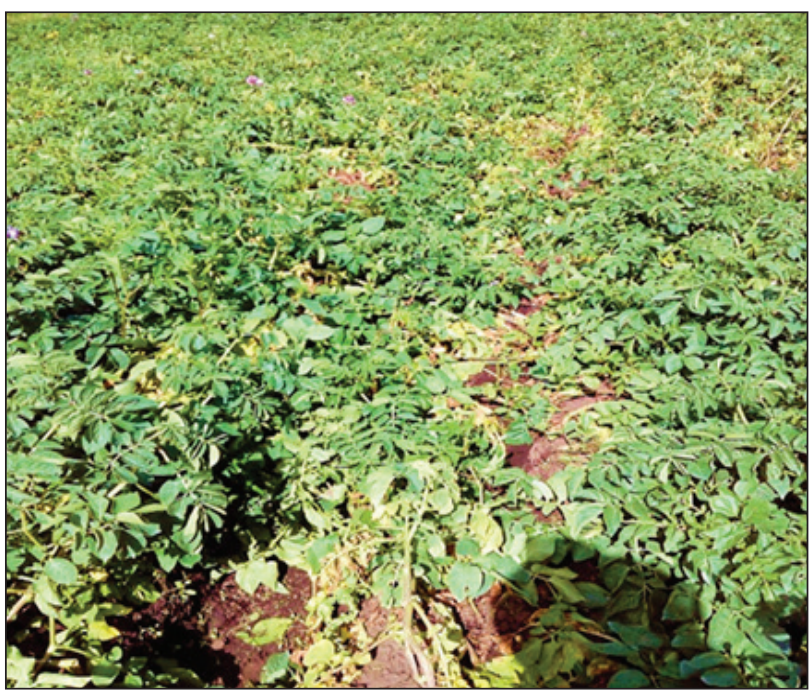

a.

Location: Túquerres - Igua.

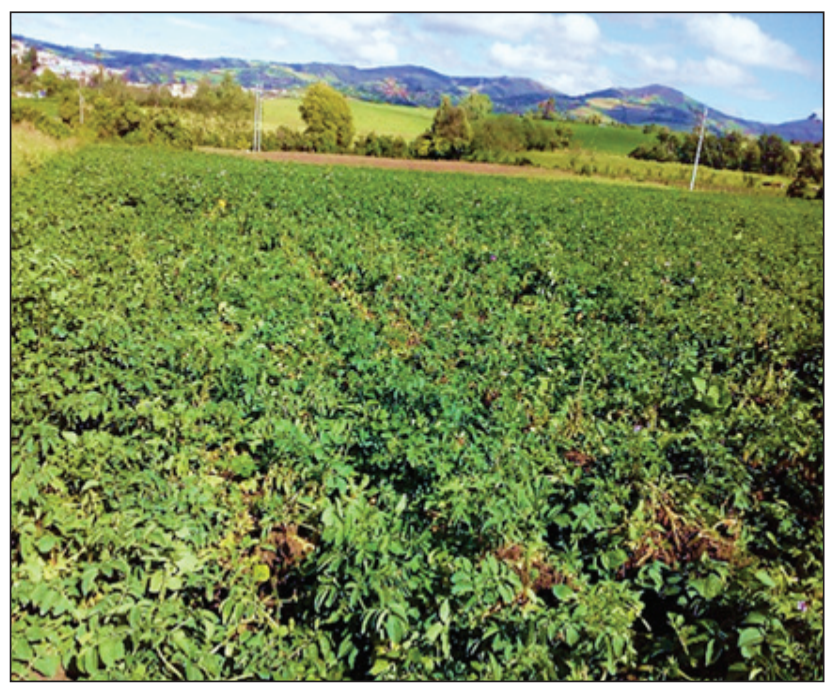

b.

Figure 2. a) Premature wilting of plants; b) Partial yellowing of plants.

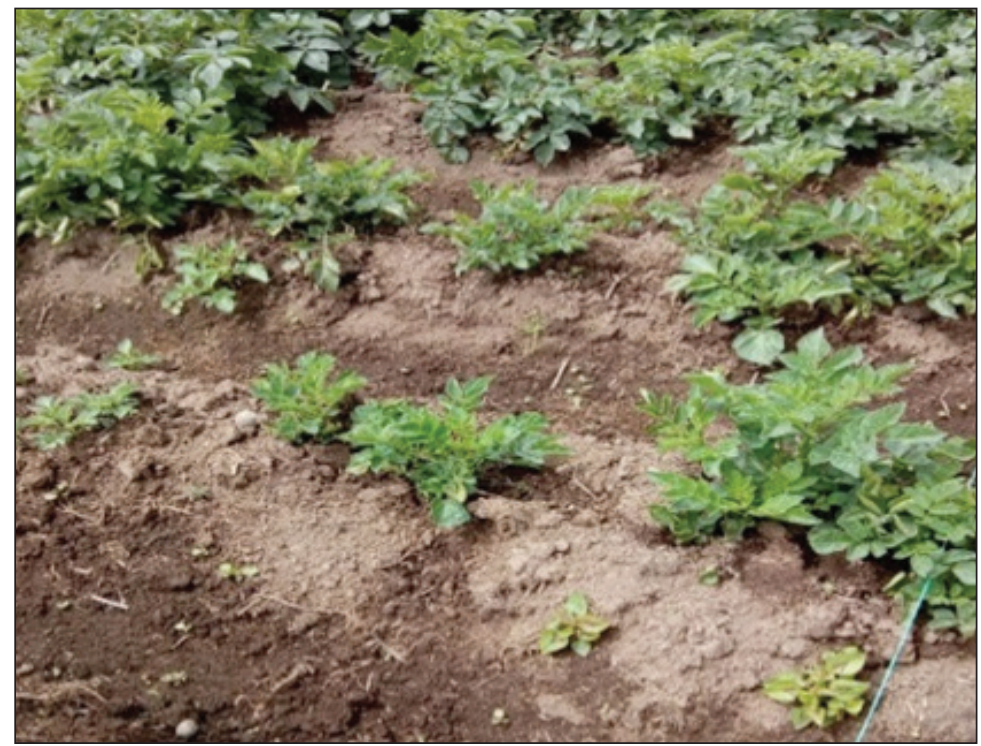

Location: Contadero.

Figure 3. Patches of dwarf potato plants.

The root system deterioration was evident, expressed in fewer roots and scarce absorbent hairs, a symptom clearly observed in Loma de Yaéz - Contadero (Figure 4). In Igua -Túquerres, immature females were found along main and some secondary roots (Figure 5). As reported by Carreño (2017), the roots reveal the presence of small spherical bodies measuring between 0.5 and $1 \mathrm{~mm}$ in diameter and are white, yellow, or brown in color. They can be seen as necklace beads. This sign causes a shortage of tubers, which generates a low yield. Furthermore, Agrios (1988) indicates that, added to the typical damages caused by the pest, these also provide the entry points for other pathogens. 

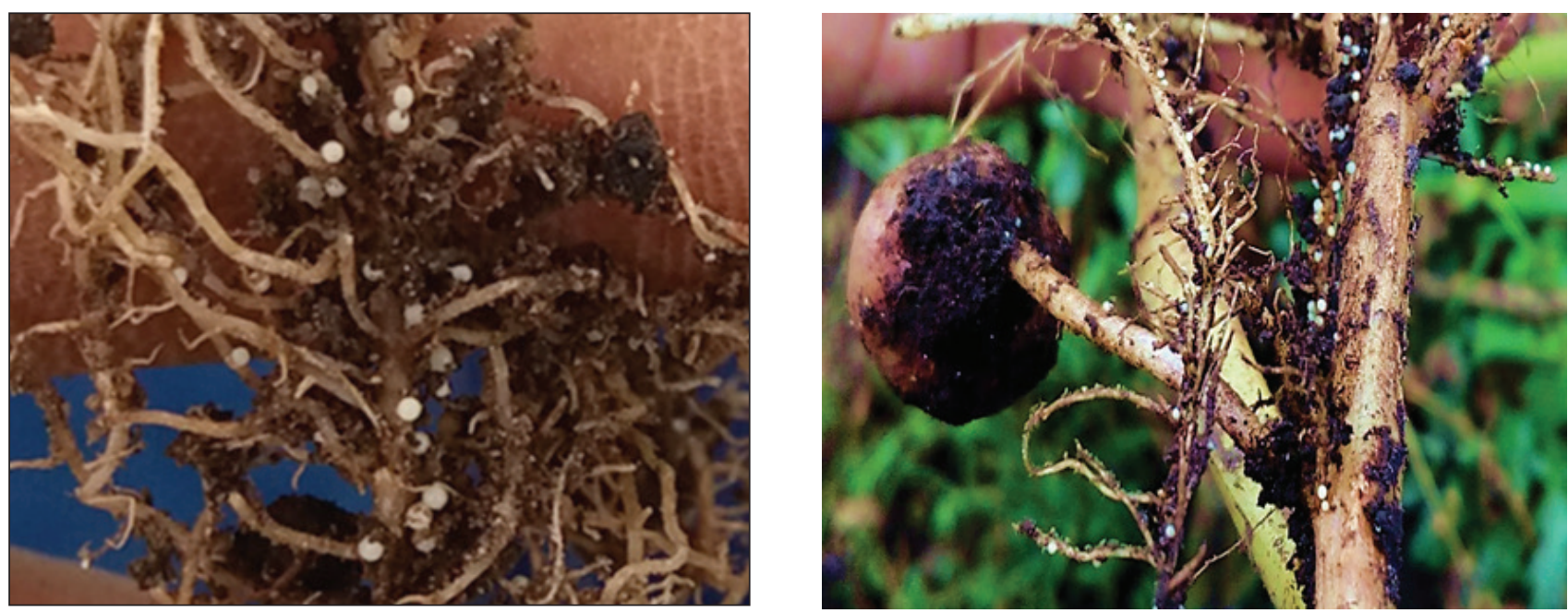

Location: Igua-Túquerres.

Figure 4. Immature females at the root, found in field.

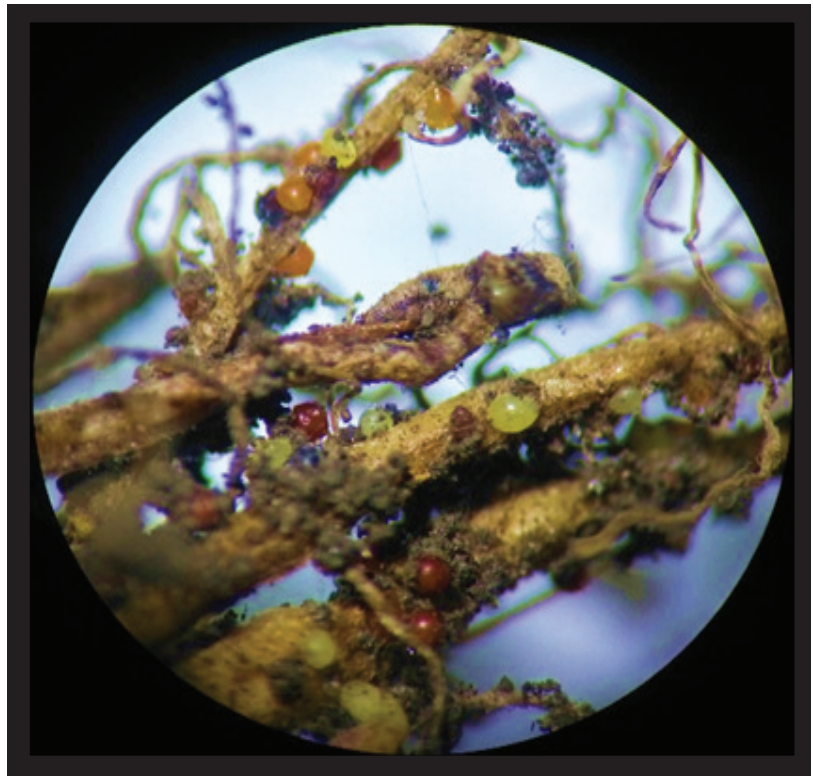

Figure 5. Immature females at the root, under a stereomicroscope. (40X)

Cyst extraction from soil. Populations showed a non-uniform spatial distribution in both localities, since symptoms were observed in foci or patches. According to Verdejo (2009), this is due to nematodes in the soil form foci or aggregates and their main dispersal mechanism is passive. That is, mediated by machinery, tools, or infected plant structures although nematodes can travel short distances by themselves.
In the areas where this study took place, air temperature oscillated from 6 to $12^{\circ} \mathrm{C}$ for Túquerres and $18^{\circ} \mathrm{C}$ for Contadero. This difference caused a dissimilarity in the number of cysts found. These ranged from 443 to 588 in Túquerres and 147 to 200 in Contadero. This is mainly due to the fact that Globodera pallida is more sensitive to high temperatures. For instance, it multiplies rapidly at temperatures of 13 to $14^{\circ} \mathrm{C}$ (Franco and Gonzales, 1992), a 
range present in Túquerres. In Contadero, a rotation with non-host nematode crops such as corn and peas was carried out; this is the opposite case to what happened in Túquerres, where the potato monoculture is the only one that has been established.

Female extraction. For the case of the town of Túquerres the evaluation carried out at 90 days showed the presence of immature females. The opposite case for Contadero area, where the females presence in the root was hardly observed. This is probably due to the difference in temperatures in the areas evaluated, since the nematodes of the species G. pallida develop more efficiently at a lower temperature, as stated by Franco and Gonzales (1992). In addition, González and Phillips (1996) state that cysts display desynchrony at the time of hatching due to unfavorable environmental conditions (quiescence) or endogenous factors (diapause). The diapause can disappear due to environment changes that become favorable or when endogenous factors allow the nematode to respond to stimuli released by the host.

Viability tests. The hatching of the cysts occurred, on average, on the fifth day. Oval eggs (Figure 6 and Figure 7) and vermiform larvae in movement, which correspond to the J2 state (Figure 8), were observed.

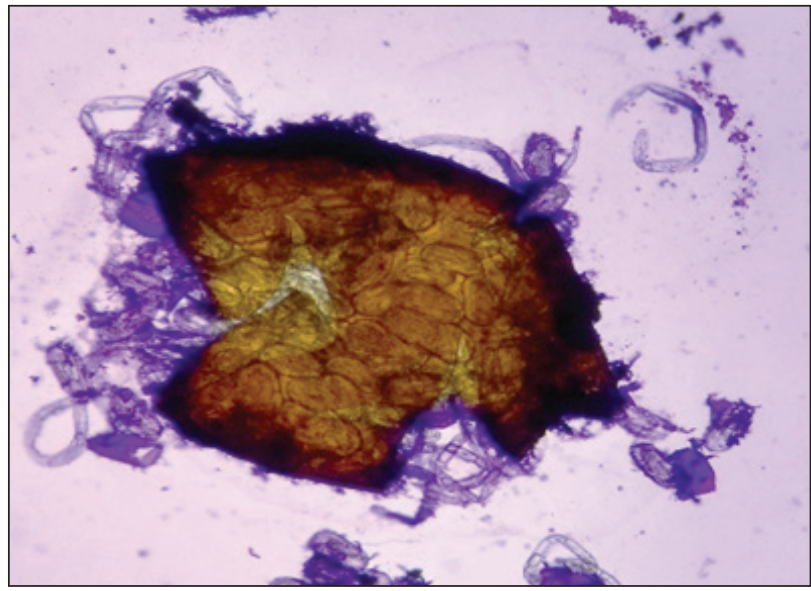

Figure 6. Viable cyst with eggs and larvae in J1 state. 40x.

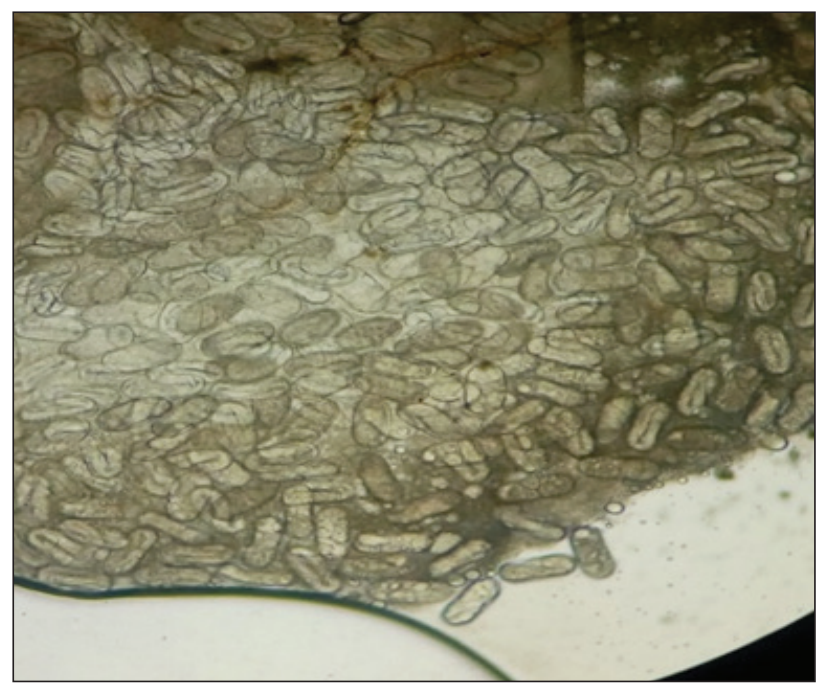

Figure 7. Unhatched eggs. 40X

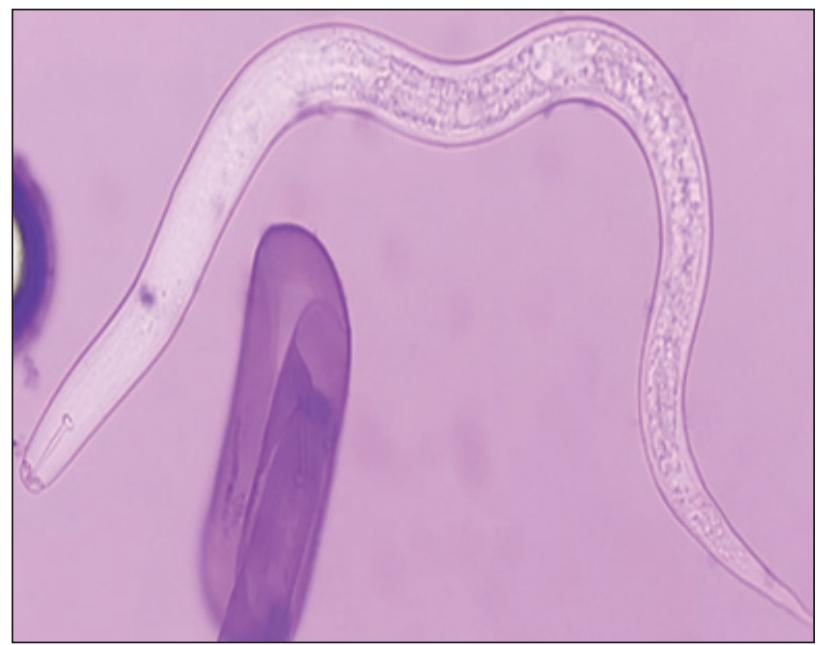

Figura 8. Larva in J2 state. 40x

Identification of the species Globodera pallida. Results of the taxonomic key used for genus (Luc, 1988) and species (Mulvey, 1959) indicate that the predominant species is Globodera pallida.

During the samplings, the color of females change in both localities, turning from white to brown in approximately 30 days. This information is in line with that provided by Egunjobi (1968). The researcher reported that in Europe, some populations of the cyst nematode were differentiated by the 
sequence in coloration during the female development towards the cyst formation, in which all mature females reached a brown color. Females went through a golden-yellow phase, and in other populations, variations of white and cream color were observed. In this way, the female maturation state, in which they change from white to yellow to later become brown cysts, belong to the species Globodera rostochiensis. Meanwhile, females that change from white to brown directly during their maturation were considered Globodera pallida (OEPP, 2017). In the sampled study area, the immature females turned from white to brown directly.

The cuticular stretch mark between the anus and the fenestra are more or less parallel, with an average number of $13 \pm 4$; the distance between the anus and the fenestra is $59.2 \pm$ $18.7 \mu \mathrm{m}$ and the length of the fenestra 24.7 $\pm 4 \mu \mathrm{m}$, characteristic features of G. pallida, as stated by Greco and Crozzoli (1995) (Figure 9). On the other hand, G. rostochiensis has crossed stretch marks and an average number of $18 \pm 3$ (Greco, 1993).

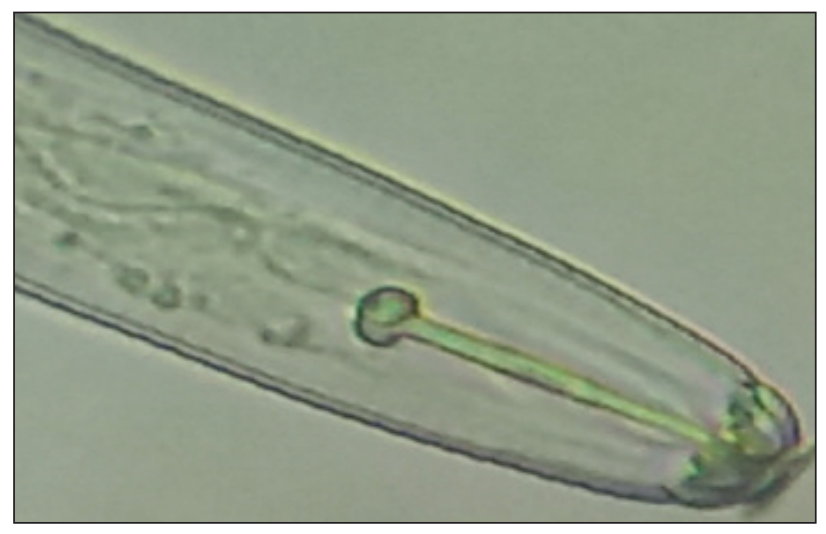

a.

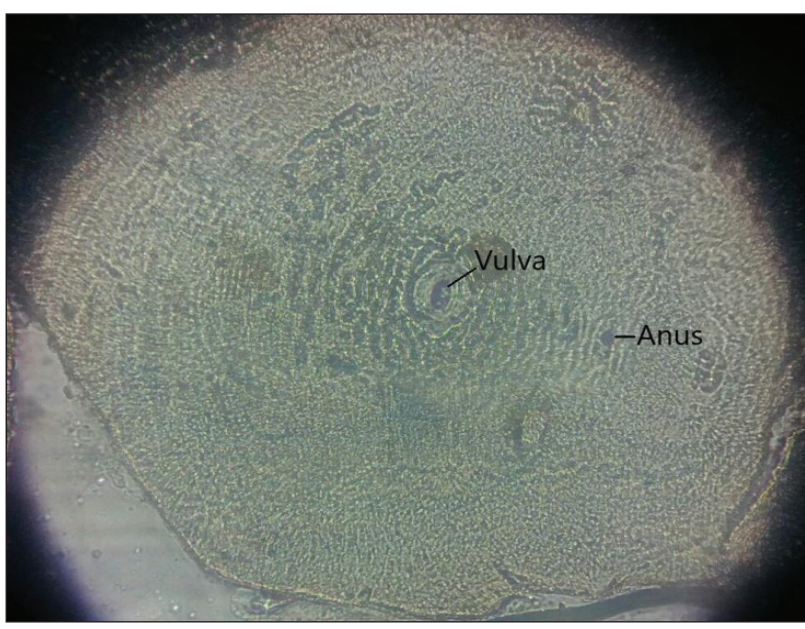

Figure 9. Perianal cut with stretch marks between the vulva and the anus. The photograph on the left corresponds to Contadero.

Obtaining juveniles. In the fifth day, the shape of the larvae was clearly observed under the microscope. Their basal nodules are directed forward, a characteristic used for the species distinction (Figure 10). As reported by Franco (1981) and Rivas (2005), G. pallida has a stylet with basal nodules pointing forward, and G. rostochiensis has a stylet with basal nodules pointing backwards.

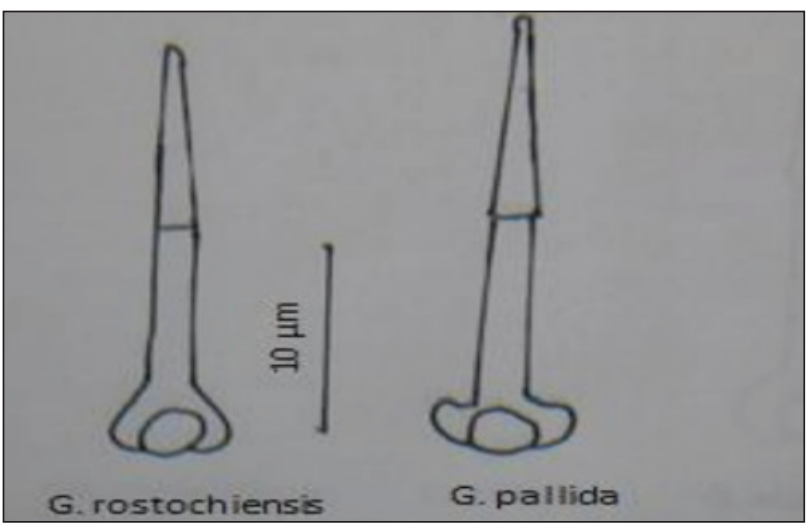

b.

a) Source: International Regional Organization for Plant and Animal Health (OIRSA);

b) Source: Self-made.

Figure 10. Direction of basal nodules of the stylet projected forward. 
Relation between phenology and crop. Desgarennes et al. (2006) and Perry (1986) consider that there is a close synchrony between the crop phenology and the biological cycle of the nematode, since the main factor for them to hatch is found in the host root exudates. Allccahuaman (2017) states that inside the cyst, the larvae can go through a resting phase, in which their hatching or emergence capacity is diminished or interrupted depending on the environmental conditions: temperature (> $30-35^{\circ} \mathrm{C}$ remain inactive), illumination (at constant illumination there is no rest), and host absence.

Once they find the ideal conditions, a change occurs in the cuticle permeability inside the egg. This allows the juveniles to absorb enough water and initiate their metabolism. Juveniles hatch by repeatedly puncturing the egg cuticle with their stylet and emerging from the cyst in J2 state through its natural openings: vulva and neck (Beltrán, 2016; Desgarennes et al., 2006). Based on the above, it is estimated that the beginning of the nematode cycle begins 20 days after the sowing. That is the moment when root growth occurs, a stage that corresponds to growth state II (active growth of roots and leaves) (Carrión and Rojas, 2013; Molina et al., 2004). It is important to highlight that the J2 state of the nematode corresponds to the invasive one and the only susceptible to nematicides (Paucar, 2016).

J2 penetrates the root near the growth point, moves inwards, cutting the cell walls with its stylet, and remains there for two more molts (Rivas, 2005). Nematodes cannot survive for more than 7 days without finding a host. Sex is defined in the third state (Paucar 2016).
Females stay in the root until they become a cyst, while males leave the root and survive only 10 days. During that time period, males fertilize females (Coto, 2005; Rivas, 2005).

The appearance of immature females coincided with the flowering stage. At that point, the sample was taken in the study plots, confirming what was stated by Desgarennes et al. (2006) and Perry (1986). They also point out that the life cycle for $G$. pallida ranges from 90 to 100 days, thus occurring only one biological cycle per growing season. The findings are in line with the results obtained by Caicedo and Canal (1980) who carried out similar studies in the department of Nariño.

In the development of this research, performance tests were not administered since there was no healthy comparator; however, plants showed scarce tuberization, which would affect the total yield.

\section{CONCLUSIONS}

From the morphological characters analyzed, the presence of Globodera pallida is confirmed in both localities, and the existence of Globodera rostochiensis is not reported in Túquerres and Contadero areas.

Temperature was an important factor, since it regulates the population dynamics of the nematode as evidenced in Igua (Túquerres), where a greater number of cysts were found compared to Loma de Yaéz (Contadero).

Conflict of interest: The authors declare that there is no conflict of interest. 


\section{BIBLIOGRAPHIC REFERENCES}

Agrios, G. N. (1988). Fitopatología. Trad. por Manuel Guzmán. 2 ed. México: Limusa. 838p.

Allccahuaman, B. R. (2017). Respuesta nematológica y agronómica de diez clones de Solanum tuberosum "papa" al Globodera pallida Stone en invernadero. Universidad de San Cristóbal de Huamanga. Ayacucho, Perú. Recovered from http://repositorio.unsch. edu.pe/bitstream/handle/UNSCH/1667/ TESIS\%20B786_All.pdf

Baeza, A. (1972). El nematodo dorado (Heterodera rostochiensis Woll.) En Colombia. Rev. Nematropica. 2(1):1-15.

Bates, J.; Taylor, E.; Gans, P.; Thomas, J. (2002). Determination of relative proportions of Globodera species in mixed populations of potato cyst nematodes using PCR product melting peak analysis. Rev. Molecular Plant Pathology. 3(3):153-161. doi: https://doi. org/10.1046/j.1364-3703.2002.00107.x

Beltrán, A. (2016). Efecto de extractos acuosos de compost y del follaje de árboles nativos en la eclosión de juveniles de Globodera rostochiensis. Universidad Austral de Chile. Memoria presentada para la obtención del título de Ingeniero Agrónomo. Valdivia, Chile. Recovered from http://cybertesis.uach.cl/ tesis/uach/2016/fab452e/doc/fab452e.pdf

Brodie, B. (1996). Golden nematode: A success story for biological control. Cornell University Ithaca, New York. Recovered from http:// web.entomology.cornell.edu/shelton/cornellbiocontrol-conf/talks/brodie.html

Caicedo, G.; Canal, J. (1980). Ciclo de vida del nematodo quiste de la papa Globodera pallida Stone en el altiplano de Pasto. Pasto, Colombia: Universidad de Nariño.

Carreño, H. (2017). Identificación de genes regulados diferencialmente en respuesta a la infección por Globodera pallida en una variedad de papa resistente y otra susceptible al nematodo. Recovered from http://repositorio. upch.edu.pe/bitstream/handle/upch/752/ Identificacion_CarrenoFern\%C3\%A1ndez_ Hans.pdf

Carrión, Y.; Rojas, D. (2013). Distribución poblacional del nematodo quiste de la papa (Globodera spp) en dos zonas productoras de los Municipios de Tausa (Cundinamarca) y Ventaquemada (Boyacá). Recovered from http://repository.uniminuto.edu/bitstream/ handle

CIMMYT-Centro internacional de mejora del Maíz y trigo., IITA- Instituto Internacional de Agricultura. (2007). Nematología práctica: Una guía de campo y laboratorio. Recovered from https://www.researchgate. net/publication/237249582_Nematologia_ practica_Una_guia_de_campo_y_laboratorio

Coto, A. (2005). El nematodo blanco de la papa (Globodera pallida. Stone). Ministerio de agricultura y ganadería servicio fitosanitario del estado. Gerencia de vigilancia y control de plagas. Cartago, Costa Rica. Recovered from http://www.mag.go.cr/bibioteca_virtual_ ciencia/nematodo_blanco.pdf

Dees, J.; Guerrero, O.; Mulder, A. (1980). Algunas observaciones de la biología y dinámica de las poblaciones de Globodera pallida Stone en Nariño. Recovered from https://repository. agrosavia.co/handle/20.500.12324/20837

Desgarennes, D.; Carrión, G.; Núñez-Sánchez A. E.; Núñez-Camargo, M. C. (2006). Distribution of stages and in vitro larval hatching in Globodera rostochiensis cysts. Nematropica. 36(2): 251260.

Franco, J. (1981). Nematodo quiste de la papa. CIP Centro Internacional de la Papa. Boletín de información técnica. Recovered from http:// cipotato.org/wp-content/uploads/2014/09/ TIBes20558.pdf

Franco, J. (1986). Nematodos del quiste de la papa; Globodera spp. Boletín de Información Técnica 9. Centro Internacional de la Papa, Lima, Perú. 
20. Recovered from https://books.google.es/ books?id=oeoVI-E5c_UC\&printsec $=$ frontcover $\& \mathrm{hl}=$ es $\&$ source $=$ gbs_ge_summary_r $\&$ cad $=0 \# \mathrm{v}=$ onepage \&q\&f=false

Franco, J.; Gonzáles, A. (1992). Manejo integrado del nematodo quiste de la papa, Globodera spp. Centra Internacional de la Papa. Lima, Perú. Recovered from https://dialnet.unirioja.es/ descarga/articulo/5512053.pdf

Franco, P.; Gonzáles, A. (2011). Pérdidas causadas por el nematodo quiste de la papa (Globodera sp) en Bolivia y Perú. Rev. Latinoamericana de la papa. 16(2): 25-30. doi https://doi. org/10.37066/ralap.v16i2.180

Fullaondo, A. (1999). Caracterización Genética del Nematodo del Quiste de la Patata Globodera pallida y Globodera rostochiensis.

Recovered from https://es.calameo.com/ $\mathrm{read} / 000107446 \mathrm{ade} 6 \mathrm{ab} 4920 \mathrm{a}$

Godoy, A. T.; Gastélum, L. R.; Yáñez, J. M.; López, M. M. (2013). Nematodos fitoparásitos en el cultivo de la papa. VII seminario de avances de investigación Facultad de Agronomía de la Universidad Autónoma de Sinaloa. Recovered from https://docplayer.es/58406328-Nematodosfitoparasitos-en-el-cultivo-de-la-papa.html

González, J. A.; Phillips, M. S. (1996). Hatching behaviour of potato cyst nematodes from the Canary Islands. Journal of Nematology. 28(4): 451-456. Recovered from https://www.ncbi. nlm.nih.gov/pmc/articles/PMC2619727/

Greco, N.; Moreno, I. (1992). Influence of Globodera rostochiensis on yield of summer, winter and spring sown potato In Chile. Nematropica. 22(2):3-6. doi: 10.21307/ jofnem-2019-073

Greco, N. (1993). Nematode problems affecting potato production in subtropical climate. Nematropica. 23(2): 213-220. Recovered from https://journals.flvc.org/nematropica/article/ view/64080

Greco, N.; Crozzoli, R. (1995). Nematodos del quiste de la papa, Globodera rostochiensis y G. pallida: aspectos generales. Fitopatologia venezolana. 8(2): 26-33.
Guerrero, 0, (2012). Nematodos que afectan al cultivo de la papa. Agrosavia. Federación Colombiana de Productores de Papa Asociación de Ingenieros Agrónomos de Nariño. Recovered from http://hdl.handle. net/20.500.12324/22899

Jalata, P. (1986). Centro Internacional de la Papa [CIP]. Nematodos parásitos de la papa. Boletín de información técnica 8. Lima, Perú. Recovered from https://cursa.ihmc.us/rid=1JL7FNT7RNPN9Q7-Y6D/Nematodos\%20parasitos.CIP.pdf

Luc, M. (1988). A reappraisal of Tylenchina (Nemata) 7. The family pratylenchidae Thorne, 1449. Revue Nametol. 10(2):203. doi: 10.1.1.532.7729\&rep=rep1\&type=pdf

Massae G. (1913). Nematodes or eelworms. Kew Bulletin N. 9: 343-351. Recovered from https:// books.google.es $/$ books?hl=es\&lr=\&id $=44 \mathrm{aVdw}$ vz2pwC\&oi=fnd\&pg=PA3\&dq=Massae.+ G. +191 $3+$ Nematodes.

MADR - Ministerio de Agricultura y Desarrollo Rural. (2019). Cadena de la papa, indicadores e insumos. Minagricultura. Recovered from https://sioc.minagricultura.gov.co

Molina, J.; Mairena Santos, B.; Aguilar, L. (2004). Manejo integrado de plagas, cultivo de papa. 1ra. Edición. 7: 62. Nicaraguan Institute of Agricultural Technology [INTA]. Recovered from https://cenida.una.edu.ni/relectronicos/ RENH10M722.pdf

Mulvey, R. H. (1959). Investigation on the clover cyst nematode, Heterodera trifolii. Nematoda Heteroderida. Nematologica. 4(2): 147-156. doi: https://doi.org/10.1163/187529259X00138

Nieto, L. (1976). Aspectos generales del nematodo quiste de la papa en Nariño. Instituto Colombiano Agropecuario [ICA]. Curso sobre enfermedades y plagas de la papa en Nariño. Pasto Colombia. Recovered from https://repository.agrosavia.co/bitstream/ handle/20.500.12324/23307/22417_3176. pdf? sequence $=1 \&$ isAllowed $=y$ 
Nieto, L.; Dees, J.; Hernández, E. (1971). Convenio Colombo Holandés para el reconocimiento y control del nematodo quiste de la papa, Globodera pallida Stone. Recovered from https://repository. agrosavia.co/handle/20.500.12324/23963

Egunjobi, O.A. (1968). An ecological study of some soil nematodes associated with apple trees in a New Zealand grassed orchard. Rev. New Zealand Journal of Agricultural Research. 11(2): 386406. doi: https://doi.org/10.1080/00288233.1 968.10431437

OEPP - Organization European Et Mediterranean Plant Protection. (2017). Globodera rostochiensis and Globodera pallida. 47: 174- 197. doi: https://doi.org/10.1111/epp.12391

OIRSA - Organismo Internacional Regional de Sanidad Agropecuaria. (2015). Ficha técnica nematodo dorado Globodera rostochiensis. Recovered from http://oirsa.org/contenido/ d o cumentos / F I C H A \% 20 T E C N I C A \% 20 NEMATODO\%20DORADO.pdf

Paucar, L. (2016). Evaluación de nematodos de quiste asociados al cultivo de papa Solanum tuberosum L. en el centro poblado de Huancabamba - Andahuaylas - Apurímac. Recovered from https://alicia.concytec.gob.pe/ vufind/Record/UTEA_267e49fb2be5a5d40bf 7 dcc3b3979659

Perry, R.N. (1986). Physiology of hatching. In: Lamberti, F.; Taylor, C.E. (eds). Cyst nematodes. pp. 119-131. New York: Springer, Boston, MA. doi: https://doi.org/10.1007/978-1-46132251-1_6

Piedra, R.; Obregón, M.; Vargas, C.; Avilés, J.; Meckbel, J. (2008). Identificación de razas del nematodo de quiste de la papa (Globodera pallida (Stone) con diferenciales o clones de papa. Rev. Alcances tecnológicos. 6(1):73-74. doi: https://doi.org/10.35486/at.v6i1.67

Rivas, E. (2005). Determinación de la preferencia de nematodos de quiste asociados al cultivo de la papa Solanum tuberosum en los municipios de Patzún y Zaragoza, Chilmantengo. Recovered from http://biblioteca.usac.edu.gt/ tesis/01/01_2209.pdf
Sañudo, B., Salazar, C.; Betancourth, C. (2003). Principios de nematología agrícola. San Juan de Pasto, Colombia: Editorial Universidad de Nariño. 120p.

SIPSA - Sistema de Información de Precios y abastecimiento del Sector Agropecuario. (2013). El cultivo de papa, solanum tuberosum alimento de gran valor nutritivo, clave en la seguridad alimentaria global. Recovered from https://www.dane.gov.co

NPDRS - National Plant Disease Recovery System. (2013). Recovery Plan for Root-Knot and Cyst Nematodes Parasites of Agronomic and Horticultural Plants Throughout North America. Recovered from https://www.ars.usda.gov

Tarazón, H. M.; Rueda-Puente, E.; GarcíaHernandez, J.; Murillo-Amador, B.; HolguínPatiño, R. (2006). Presencia del nematodo dorado Globodera rostochiensis (Wollenweber) Skarbilovich, en Lotes de Papa (Solanum tuberosum L.) del Estado de Coahuila, México. Revista Mexicana de Fitopatología. 24 (1): 24-26.

Tovar, A. (2006). El nematodo dorado de la papa Globodera rostochiensis. Recovered from http://repositorio.uaaan.mx:8080

Valbuena, R.; Roveda, G.; Bolaños, A.; Zapata, J.; Medina, C.; Almanza, P.; Porras, P. (2009). Escalas fenológicas de las variedades de papa, parda pastusa, Diacol capiro y Criolla "yema de huevo" en las zonas productoras de Cundinamarca, Boyacá, Nariño y Antioquia. Recovered from http://hdl.handle.net/20.500.12324/12893

Valverde, W. (2011). Comportamiento de 24 accesiones de papa (nativas, comerciales y clones promisorios) al parasitismo del nematodo del quiste de la papa (Globodera pallida) en invernadero. Cutuglagua- Pichincha. Recovered from https://www.researchgate. net/publication/305001163

Vera, N.; Oliva, M. (2013). Nematodos fitoparásitos asociados al cultivo de papa (Solanum tuberosum L.) en la provincia de Luya, Amazonas. Rev. INDES. 1(2):94-101. doi: http:// dx.doi.org/10.25127/indes.20131.57 
Verdejo, S. (2009). Manejo integrado de nematodos. Recovered from https://www.recercat.cat/ bitstream/handle/2072/39528/Verdejo_09. pdf?sequence $=1$

Zumeta, J. (2016). Métodos para la extracción de nematodos. Laboratorio de introducción a la fitopatología. Recovered from https://www. es.scribd.com 